\title{
Kasviperäisen indigon värinkesto-ominaisuudet
}

\author{
Eeva Mussaari ${ }^{1)}$, Anne Vuorema ${ }^{2)}$ ja Marjo Keskitalo ${ }^{2)}$ \\ ${ }^{1}$ Helsingin yliopisto, Kasvatustieteellinen tiedekunta, Kotitalous- ja käsityötieteiden laitos, Siltavuo- \\ renpenger 10 (PL 8),00014 Helsingin yliopisto,eeva.mussaari@helsinki.fi \\ ${ }^{2}$ Maa- ja elintarviketalouden tutkimuskeskus, Kasvinviljely- ja biotekniikka, 31600 Jokioinen, \\ marjo.keskitalo@mtt.fi,anne.vuorema@mtt.fi
}

\section{Johdanto}

Ihminen on osannut hyödyntää luonnosta saatavia väriaineita jo yli neljän vuosituhannen ajan mm. tekstiilien värjäykseen. Sininen indigo oli vaativan värjäysprosessinsa ja vaikean saatavuutensa vuoksi koko luonnonväriaikakauden ajan yksi arvokkaimmista väriaineista. Se erottui muista kasviperäisistä siniväreistä myös hyvän värinkestonsa ansiosta, sillä useimmille luonnonväreille on tyypillistä huono kestävyys.

Värimorsinko (Isatis tinctoria) on ainoa Suomen olosuhteissa menestyvä merkittävästi väriainetta sisältävä indigokasvi. Se on vanhin Euroopassa tunnettu sinivärikasvi ja myöhäiskeskiajalta 1800luvun lopulle sitä viljeltiin maanosassamme laajalti. Luonnonvärien aikakausi katsotaan päättyneeksi 1800-luvun lopulla, jolloin synteettisesti valmistetut värit yleistyivät. Sen jälkeen indigontuottajakasvit unohdettiin Euroopassa pitkäksi aikaa.

Kasvi-indigon käyttökelpoisuus nykyaikaisissa tekstiileissä riippuu suurelta osin sen värinkestosta. Värin sitoutumisesta kuituun tulee syntyä riittävät ja käyttötarkoituksenmukaiset värinkestoominaisuudet. Valmiilta tuotteilta vaaditaan muun muassa valon-, pesun-, hankauksen-, hien- ja merivedenkesto-ominaisuuksia. On olennaista, että suunniteltavan tuotteen käyttöprofiili otetaan huomioon väriainetta valittaessa, sillä värinkestovaatimukset vaihtelevat käyttötarkoituksen mukaan. Erilaisten käyttökohteiden löytyminen indigolle taas on edellytyksenä morsinkoviljelyn mahdollisuudelle ylipäätään kehittyä uudeksi elinkeinoksi.

\section{Aineisto ja menetelmät}

Tässä tutkimuksessa verrattiin viiden eri indigolähteen vaikutusta villan värjäytymiseen. Vertailtavina indigolähteinä olivat MTT:ssä (suomalainen, viileäeristys) ja Englannissa tuotetut morsinkoindigot sekä trooppisen Indigofera tinctoria -kasvin indigo. Suomalainen väriaine oli nestemäisenä liuoksena ja englantilainen jauheeksi kuivattuna. Indigofera tinctorian indigoa oli sekä tiiviinä väriainekakkuna että kasvin kuivattuna lehtenä. Verranteena oli synteettisesti valmistettu indigo.

Eri lähteistä peräisin olevilla indigoilla värjättiin villankangasta hydrosulfiittikyypissä, jossa vaikuttavina ainei-

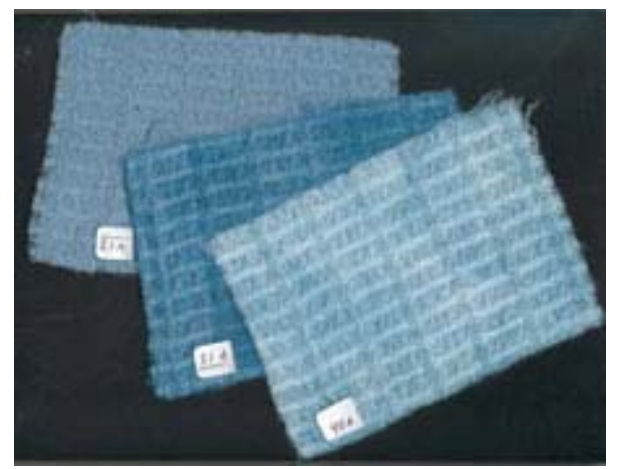
na olivat pelkistimenä natriumditioniitti $\left(\mathrm{Na}_{2} \mathrm{~S}_{2} \mathrm{O}_{4}\right)$ ja emäksenä natriumhydroksidi $(\mathrm{NaOH})$. Värjättyjen villakankaiden valon-, pesun- ja hankauksenkestot määritettiin.

Värin valonkeston testaus suoritettiin SFS-EN ISO 105-B02 standardin mukaan. Näytteitä valotettiin 200 tunnin ajan. Värinmuutokset arvosteltiin 8-askelisen siniasteikon (1 =huonoin, 8 =paras) mukaan, harmaa-asteikon (SFS-EN 20105-A02) avulla. Värin pesunkestotesti suoritettiin SFS-EN ISO 105-C06 standardin mukaan. Näytteiden värinmuutos ja testikankaan tahriutuminen arvosteltiin SFS-EN 20105-A02- ja -A03- standardien mukaisten harmaa-asteikkojen avulla. Asteikot ovat 9portaisia arvosana-asteikkoja $(1,1 / 2,2 \ldots 5)$, joissa 5 on paras arvo. Värin hankauksenkesto testattiin SFS-EN ISO 105-X12 standardin mukaan ja hankauskankaiden tahriutuminen arvosteltiin harmaaasteikolla (SFS-EN 20105-A03). 


\section{Tulokset ja tulosten tarkastelu}

Valonkestoltaan kaikki näytekankaat saivat vähintään siniasteikon arvon 3 (Taulukko 1). Pienimmän arvon sai kuitenkin vain yksi näyte (Indigofera tinctorian lehti-indigo), muut samankin väriaineen toistot saivat arvoja 4-5:stä 5:een. Toistojen keskiarvoja verrattaessa näillä näytteillä oli muiden kyyppien näytteisiin verrattuna huonoin värin valonkesto (4). Parhaimmat värin valonkestoarvot saivat suomalaisella morsinkoindigolla värjätyt näytteet. Sillä värjättyjen neljän värjäystoiston saamat arvot vaihtelivat viidestä yli kuuteen. Kahden suomalaisen morsingon indigolla värjätyn näytteen osalta testi ei ollut standardin mukainen, sillä $200 \mathrm{~h}$ valotuksen aikana niissä ei tapahtunut lainkaan värinmuutosta. Muiden indigovärien valonkestoarvot vaihtelivat neljän ja kuuden välillä.

Taulukko 1. Värin valonkestotulokset näytekankaiden toistojen keskiarvoina (x). s kertoo toistojen keskihajonnan ja W niiden vaihteluvälin. Siniasteikko on 8-portainen asteikko, jossa 1 = huonoin valonkesto, 8 = valo ei aiheuta minkäänlaista värinmuutosta. Näytteet voivat saada myös puoliväliarvoja, kuten $4-5$.

\begin{tabular}{l|ccc}
\hline Värjätty näyte & \multicolumn{3}{|c}{ Värin valonkesto } \\
\hline \hline Suom. morsinko & $\mathbf{x}$ & $\mathbf{s}$ & $\mathbf{W}$ \\
Engl. morsinko & 5,88 tai yli & 0,25 tai yli & $(5-6,6$ tai yli) \\
Indigoferan lehti & 4,63 & 0,25 & $(4-5,5)$ \\
Indigofera-kakku & 4,25 & 0,87 & $(3,5)$ \\
Synt. Indigo & 5,13 & 0,25 & $(5,5-6)$ \\
& 4,88 & 0,85 & $(4,6)$ \\
\hline
\end{tabular}

Näytekankaiden värin pesunkestotulokset ovat nähtävillä taulukossa 2. Pesunkestoltaan parhaita olivat englantilaisella morsinkoindigolla, Indigofera tinctoria -kakulla ja synteettisellä indigolla värjätyt näytteet. Niissä ei tapahtunut testissä minkäänlaista värinmuutosta eivätkä ne aiheuttaneet testikankaiden tahriutumista. Suomalaisen morsinkokyypin yhdessä toistossa oli vähäistä vaalenemista pesun jälkeen. Eniten väriä päästivät Indigofera tinctorian kuivatuilla lehdillä värjätyt kankaat. Sen näytteistä jokaisessa tapahtui pesun aikana vähäinen (4) tai keskisuuri (3) värinmuutos.

Taulukko 2. Eri lähteistä peräisin olevan indigon värin pesunkestotulokset näytekankaiden toistojen keskiarvoina (x). s kertoo toistojen keskihajonnan ja W niiden vaihteluvälin. Keskiarvoja ja keskihajontaa laskettaessa puoliväliarvot on merkitty desimaalilukuina.

\begin{tabular}{l|ccc|ccc|ccc}
\hline \multirow{2}{*}{ Värjätty näyte } & \multicolumn{4}{|c|}{} & \multicolumn{5}{|c}{ Testikankaan tahriutuminen } \\
& \multicolumn{2}{|c}{ Näytteen värinmuutos } & \multicolumn{4}{c}{ Villa } & \multicolumn{4}{c}{ Puuvilla } \\
& $\mathbf{x}$ & $\mathbf{s}$ & $\mathbf{W}$ & $\mathbf{x}$ & $\mathbf{s}$ & $\mathbf{W}$ & $\mathbf{x}$ & $\mathbf{s}$ & W \\
\hline \hline Suom. morsinko & 4,75 & 0,5 & $(4,5)$ & 4,88 & 0,25 & $(4 / 5,5)$ & 5 & 0 & $(5,5)$ \\
Engl. morsinko & 5 & 0 & $(5,5)$ & 5 & 0 & $(5,5)$ & 5 & 0 & $(5,5)$ \\
Indigoferan lehti & 3,5 & 0,58 & $(3,4)$ & 4,88 & 0,25 & $(4 / 5,5)$ & 5 & 0 & $(5,5)$ \\
Indigofera-kakku & 5 & 0 & $(5,5)$ & 5 & 0 & $(5,5)$ & 5 & 0 & $(5,5)$ \\
Synt. Indigo & 5 & 0 & $(5,5)$ & 5 & 0 & $(5,5)$ & 5 & 0 & $(5,5)$ \\
\hline
\end{tabular}

Hankauksenkestoltaan eri lähteistä peräisin olevat indigot olivat hyvin tasavertaisia (Taulukko 3). Kaikki näytteet saivat kuivalla testikankaalla sekä loimen että kuteen suuntaan hangattaessa arvon 5, eli testikangas ei tahriutunut lainkaan. Märällä testikankaalla sekä kuteen että loimen suuntaan hangattaessa kaikki näytteet saivat vastaavasti arvon 4/5. Märällä testikankaalla hangattaessa näytteistä siis irtosi vähän väriä. 
Taulukko 3. Värin hankauksenkestotulokset näytekankaiden toistojen keskiarvoina (x) harmaa-asteikolla (SFSEN 20105-A03) arvosteltuna. s kuvaa toistojen saamien arvojen keskihajontaa ja W niiden vaihteluväliä. Taulukossa on erikseen kuvattu kuiva- ja märkähankaustulokset. Käytetty harmaa-asteikko on yhdestä viiteen kulkeva, 9-askelinen arvosana-asteikko, jossa on käytössä arvojen puolivälit. Arvosanat $1,1 / 2,2 \ldots 5$ (1 =hankauskangas on tahriutunut voimakkaasti, 5 =hankauskangas ei ole lainkaan tahriutunut).

\begin{tabular}{|l|}
\hline $\begin{array}{l}\text { Värjätty } \\
\text { näyte }\end{array}$ \\
\hline $\begin{array}{l}\text { Suom. } \\
\text { Morsinko }\end{array}$ \\
\hline $\begin{array}{l}\text { Engl. } \\
\text { Morsinko }\end{array}$ \\
\hline $\begin{array}{l}\text { Indigofe- } \\
\text { ran lehti }\end{array}$ \\
\hline $\begin{array}{l}\text { Indigofe- } \\
\text { ra-kakku }\end{array}$ \\
\hline $\begin{array}{l}\text { Synteetti- } \\
\text { nen Indigo }\end{array}$ \\
\hline
\end{tabular}

\begin{tabular}{|ccc|ccc|}
\hline \multicolumn{6}{|c|}{ Kuivahankaus } \\
\hline \multicolumn{5}{|c|}{ Loimi } \\
$\mathbf{x}$ & $\mathbf{W}$ & $\mathbf{x}$ & $\mathbf{S}$ & $\mathbf{W}$ \\
\hline 5 & 0 & $(5,5)$ & 5 & 0 & $(5,5)$ \\
\hline 5 & 0 & $(5,5)$ & 5 & 0 & $(5,5)$ \\
\hline 5 & 0 & $(5,5)$ & 5 & 0 & $(5,5)$ \\
\hline 5 & 0 & $(5,5)$ & 5 & 0 & $(5,5)$ \\
\hline 5 & 0 & $(5,5)$ & 5 & 0 & $(5,5)$ \\
\hline
\end{tabular}

\begin{tabular}{|ccc|ccc|}
\hline \multicolumn{6}{|c|}{ Märkähankaus } \\
\hline \multicolumn{5}{|c|}{ Loimi } \\
$\mathbf{x}$ & $\mathbf{W}$ & $\mathbf{W}$ & $\mathbf{x}$ & $\mathbf{s}$ & $\mathbf{W}$ \\
\hline $4 / 5$ & 0 & $\begin{array}{c}(4 / 5, \\
4 / 5)\end{array}$ & $4 / 5$ & 0 & $\begin{array}{c}(4 / 5, \\
4 / 5)\end{array}$ \\
\hline $4 / 5$ & 0 & $\begin{array}{c}(4 / 5, \\
4 / 5)\end{array}$ & $4 / 5$ & 0 & $\begin{array}{c}(4 / 5, \\
4 / 5)\end{array}$ \\
\hline $4 / 5$ & 0 & $\begin{array}{c}(4 / 5, \\
4 / 5)\end{array}$ & $4 / 5$ & 0 & $\begin{array}{c}(4 / 5 \\
4 / 5)\end{array}$ \\
\hline $4 / 5$ & 0 & $\begin{array}{c}(4 / 5, \\
4 / 5)\end{array}$ & $4 / 5$ & 0 & $\begin{array}{c}(4 / 5 \\
4 / 5)\end{array}$ \\
\hline $4 / 5$ & 0 & $\begin{array}{c}(4 / 5, \\
4 / 5)\end{array}$ & $4 / 5$ & 0 & $\begin{array}{c}(4 / 5 \\
4 / 5)\end{array}$ \\
\hline
\end{tabular}

\section{Johtopäätökset}

Tulosten perusteella indigon alkuperällä näyttää olevan vaikutusta värin valon- ja pesunkestoon, muttei hankauksenkestoon värjättäessä villaa käytetyllä menetelmällä. Parhaimmat värinkestot mitattiin Indigofera tinctorian kakku-indigolla, suomalaisella morsinkoindigolla ja synteettisellä indigolla värjätyistä näytteistä. Huonoin kesto oli Indigofera tinctorian lehti-indigolla, joka oli myös vertailluista väriaineista epäpuhtainta.

Valonkestotestissä saadut arvot ovat aiemmin tehtyihin tutkimuksiin verrattuna (vrt. Hannusas \& Raitio 1997; Lummi 2003) hyvin positiivisia. Hankauksenkestotestin antamat hyvät arvot taas vahvistavat aiempia suomalaisia tutkimustuloksia (ks. emt), jotka kuitenkin ovat antaneet hyvin ristiriitaisen tuloksen värjäyskirjallisuuden esittämiin verrattuna. Indigon huonoimpana ominaisuutena on yleensä nimenomaan mainittu hankauksenkesto.

Tutkimustulosten perusteella voidaan päätellä eri lähteistä saatujen indigoiden soveltuvuutta eri tyyppisten tekstiilien värjäykseen. Valon kannalta vaativiin olosuhteisiin, kuten seinätekstiileiksi tai verhoiksi, soveltuu vertailluista väriaineista parhaiten suomalaisen morsingon indigo. Indigofera tinctorian kakkuindigo on suositeltavin sellaisten sisustustekstiilien värjäykseen, joita valon lisäksi rasittavat usein toistuvat pesukerrat. Vaatetuskäyttöön tarkoitettujen tekstiilien värjäykseen soveltuvat ne indigot, joiden pesun- ja hankauksenkestot ovat hyvät. Näiden tutkimustulosten mukaan erityisesti Indigofera tinctorian kakkuindigo, englantilainen morsinkoindigo ja synteettinen indigo ovat tällaisia. Tutkimuksen perusteella Indigofera tinctorian kuivattua lehteä ei voida suositella indigovärjäykseen.

\section{Kirjallisuus}

Balfour-Paul, J. 1998. Indigo. London: British Museum.

Hannusas, S. \& Raitio, S. 1997. Morsinkovärjäys. Historiaa ja kokeiluja. Monisteita 12. Turku: Turun maakuntamuseo.

Keskitalo, M. 2002a. Kasviväritutkimus Suomessa. Esimerkkinä kansainvälinen sinistä kasviväriainetta tutkiva SPINDIGO-projekti. Teoksessa Kauno. Kasvivärien tuotekehitysprojektin tiedotuslehti. No 1. Vantaa: EVTEKMuotoiluinstituutti, 26.

Kokubun, T., Edmonds, J. \& John, P. 1998. Indoxyl Derivatives in Woad in Relation to Medieval Indigo Production. Phytochemistry 49 (1), 79-87.

Lummi, E. 2003. Opinnäytetyönä luonnonvärien värinkesto-ominaisuuksien testauksia. Teoksessa Kauno. Kasvivärien tuotekehitysprojektin tiedotuslehti. No. 2. Vantaa: EVTEK-Muotoiluinstituutti, 64-66.

Räisänen, R. 2002. Anthraquinones from the Fungus Dermocybe sanguinea as Textile Dyes. Department of Home Economics and Craft Science. Research Report 10. Helsinki: University of Helsinki.

SFS-EN ISO 105-A01-1996. Tekstiilit. Värinkestot. Osa A01: Testauksen yleiset periaatteet. Helsinki: Suomen standardisoimisliitto. 
SFS-EN 20105-A02-1995. Tekstiilit. Värinkestot. Osa A02: Harmaa-asteikko värinmuutoksen arvostelemiseksi. Helsinki: Suomen standardisoimisliitto.

SFS-EN 20105-A03-1995. Tekstiilit. Värinkestot. Osa A03: Harmaa-asteikko tahriutumisen arvostelemiseksi. Helsinki: Suomen standardisoimisliitto.

SFS-EN ISO 105-B02-2000. Tekstiilit. Värinkestot. Osa B02: Värien keinovalonkesto: Ksenonkaarivalo. Helsinki: Suomen standardisoimisliitto.

SFS-EN ISO 105-X12-1995. Tekstiilit. Värinkestot. Osa X12: Värien hankauksenkesto. Helsinki: Suomen standardisoimisliitto.

SFS-EN 105-C06-1997. Tekstiilit. Värinkestot. Osa C06: Värien pesunkesto koti- ja pesulapesussa. Helsinki: Suomen standardisoimisliitto.

Sundquist, J. 1982. Tekstiilikemian historiaa. Vanha luonnonainevärjäys. Tampere: Suomen tekstiiliteknillinen liitto. 